\title{
Study on the Work Culture \& Socio-economic Conditions of the Fishing Community working as Unorganised Labourers in Coastal Mangaluru, Karnataka
}

\section{Pradeep M. D.}

Research Scholar, School of Law, Alliance University, Anekal, Bengaluru \& Assistant Professor, College of Social Sciences \& Humanities, Srinivas University, Mangaluru, Karnataka, India

Email: mdpradeepnair767@gmail.com

Type of the Paper: Research Policy.

Type of Review: Peer Reviewed.

Indexed in : OpenAIRE

DOI : http://dx.doi.org/10.5281/zenodo.1133156.

Google Scholar Citation: $\underline{\text { IJMTS }}$

\section{How to Cite this Paper:}

Pradeep, M. D. (2017). Study on the Work Culture \& Socio-economic Conditions of the Fishing Community working as Unorganised Labourers in Coastal Mangaluru, Karnataka. International Journal of Management, Technology, and Social Sciences (IJMTS), 2(2), 105115. DOI: http://dx.doi.org/10.5281/zenodo.1133156.

International Journal of Management, Technology, and Social Sciences (IJMTS)

A Refereed International Journal of Srinivas University, India.

(C) With Authors.

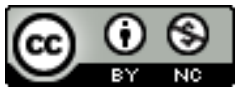

This work is licensed under a Creative Commons Attribution-Non Commercial 4.0 International License subject to proper citation to the publication source of the work.

Disclaimer: The scholarly papers as reviewed and published by the Srinivas Publications (S.P.), India are the views and opinions of their respective authors and are not the views or opinions of the SP. The SP disclaims of any harm or loss caused due to the published content to any party. 


\title{
Study on the Work Culture \& Socio-economic Conditions of the Fishing Community working as Unorganised Labourers in Coastal Mangaluru, Karnataka
}

\author{
Pradeep M. D. \\ Research Scholar, School of Law, Alliance University, Anekal, Bengaluru \& Assistant Professor, \\ College of Social Sciences \& Humanities, Srinivas University, Mangaluru, Karnataka, India. \\ Email: mdpradeepnair767@gmail.com
}

\begin{abstract}
Labour is the prime contributor for the industrial growth and economic development of a country. It is known to be the segment which contributes significantly to the GDP of the Nation. Work is generally known to be the physical or mental engagement of the people in any economically productive activity for their livelihood. The Indian economy is characterized by the existence of a vast majority of employment in the unorganised sectors. Its dominance in the employment front is such that more than 90 per cent of the total workforce belongs to the informal economy. Planned Economic Development in the country can be achieved by eliminating poverty through employment and income generation. In this regard, Fisheries sector plays an important role in the developing countries of the world. The fisheries contribution to the Indian economy has enriched after the introduction of advanced technology to increase the yield per unit area of water attracting more foreign exchange. The problems of poverty and malnutrition faced in coastal areas can be simultaneously met through, planned utilization of available local resources and encouraging participation of the local people in the fishing occupation. Fisher folk are those people who engage in fishing activities. They are the victims of economic oppression and lives under social prejudices with low social status. There is a need to undertake systematic study on the life of the fishermen to seek solutions to their existing problems and to improve their overall status. This study will review into the work life of fisher folks in Thota Bengre village belonging to Mangaluru taluk in Karnataka State.
\end{abstract}

Keywords: Labour, Employment, Income, Fisher Folk, Status, Work Life.

\section{INTRODUCTION :}

Unorganised sector is considered to be the great contributor to the Indian economy, therefore, it important to conduct extensive investigation upon the employment relationship and working conditions by considering types of occupation, regulatory mechanisms, share of contribution, challenges faced by the labourers etc. [1]. Fishery is an important sector in most of the developed and developing countries of the world from the point of generating Income and Employment. Indian Ecology with narrow strip of land connected with rivers, lagoons and back waters flowing towards the nutrient rich sea has generated enormous aquatic resources, making fish as an indispensable part of diet among the people. Fish took the stand in Indian Mythology by including in the ten incarnations of God called 'Mathsyavathara'. Famous works including Kautilya's 'Arthashastra' and King Someswara's 'Manasottara' mentions about fishing as occupation. Fisheries sector is highly productive with nutritious food, employment and export earning which stimulates the economic growth in the country. India has set a milestone by becoming second largest fish producing country in the world by recording 11.41 million tonnes productivity during 201617. The launch of 'Blue Revolution' aiming 
towards comprehensive development of Fisheries sector, with an outlay of Rs. 300 crores, have marked an increase of 18.86 per cent in the marine fishing during the last three years and 26 per cent growth in the Inland Fish productivity. In this regard Government safeguarded the interest of the traditional fishermen within the Exclusive Economic Zone (EEZ) spread beyond 12 nautical miles by adopting usage of LED lights for fishing along with banning the Bull-trailing [2].

The annual fish catch in the District, has gone up from 47, 912 tonnes (2001-02) to 1,38,506 tonnes (2011-12). There is a good scope for inland fish production by utilizing 207 tanks in the District. The Fisheries Department constituted a fish breeding centre at Pilikula. The development of fisheries are hurdled by the lack of landing facility, auction ward, water supply, drainage, electricity, ice plant and cold storage and other factors including prevalence of middlemen, over exploitation of inshore fishing, encroachment of offshore fishing by the enterprises. The regulations like The Coastal Regulation Zone (CRZ) Act prohibiting development activity within 200 meters from high tide line on the landward side and 100 meters along tidal water bodies or width of creek affects the livelihood security of the traditional fisher folks living within the 'No Development Zone'[3]. In accordance with the prevalence of high population, the demand for food and nutritional security increases simultaneously. Fishery along with supplying protein rich food also helps to build domestic food security in the coastal areas. The availability of aquatic resources, rich variety of fish species, tropical temperature have encouraged to exploit fisheries resources to the maximum. Fishing has emerged to be an industry reaching the world market [4]. Fisheries sector took deviance from the subsistence to commercial activity stands at par with agriculture and animal husbandry. The essentials for human health through balanced diet can be compensated through fish consumption, because of the presence of protein, vitamins, fat, minerals, carbohydrates etc in it. As a source of food fisheries, plays equal role with agriculture and animal husbandry
[5]. The future of the small scale fishing community can be secured through a development process by creating an economy to protect fishing community identity, rights and talents. Such process always should aim for generating growth, sustainable use of environment, empowerment of marginalized to bring self reliance [6].

(a) Description on the Study Area: According to Marine Fisheries Census, 2010, Karnataka Thota Bengre is one among the 17 fishing villages belonging to Mangaluru Taluk in Dakshina Kannada District. Thota Bengre comprises 2819 fisher folks with 570 fishermen families, 564 Traditional Fishermen Families, 208 BPL families. Among the Population living in the village, 1125 are Adults, 1129 Females and 2819 children. 617 people possess primary education, 654 people with Higher Secondary and 370 people studied above higher secondary education. Out of total 922 fisher folks, 731 are fulltime fishers and 190 are par timers and 01 involving in Seed Collection. Among 2214 occupied persons in the village, 922 are active fishermen, 441 engage in marketing, 23 in making or repairing net, 70 in curing/processing, 05 in peeling, 691 labourers, 23 in other activities and 39 employed in other than fishing activity. Among 570 people, 561 Hindus, 03 Islams and 06 Christians. Among 604 members of the Cooperatives, 304 belong to Fisheries Cooperatives and 300 to other cooperatives.

(b) Fishing Allied Activities: The Fishing industry also generates income to allied sectors such as canneries, processing establishments, gear and equipment manufacturing, boat yards, refrigeration and ice making and transport services etc. It even increase the food supply thereby helps to raise the nutrition among the people. Besides being protein rich food, fishes also yields certain byproducts such as fish oil, fish meal, fish manure, fish leather, fish glue etc.[7]. The key features such as perishable product, bulk production, consumption pattern has provided ample scope for Processing and Marketing activities. The required infrastructural support is provided by the freezing plants, canning plants, ice plants, fish meal plants, pre processing centers and cold storage. 
(c) Scope of Fisheries: Traditional fish culture in small ponds were prominently adopted in the eastern parts of the country. During 1911, Fish Culture was initially adopted by Tamil Nadu (Formar State of Madras) and subsequently, West Bengal, Punjab, Uttar Pradesh, Gujarat, Karnataka and Andra Pradesh followed it. The State of Karnataka possess 144 Marine Fishing Villages comprising (86) in Uttar Kannada, 17 in Dakshina Kannada and 41 in Udupi Districts respectively with 1,67,429 fisher folk population. It also consist 23,624 people from Below Poverty Line families, 28,533 traditional fishermen families, 30,713 fishermen families and 96 landing centres. The Dakshina Kannada District with $42 \mathrm{~km}$ Coastal Belt comprises 27,281 fisher folk population along with 14 landing centres, 17 Fishing Villages, 4,570 fishermen families, 3,941 traditional fishermen families and 1,485 people from Below Poverty Line families. Out of total 6,139 active fishermen 3,691 engage in full time, 2,383 part timers and rest 65 engage in fish seed collection respectively. Out of Total 18,173 occupied people, 6,139 are Active fishermen, 4,069 engage in marketing, 374 in repairing net, 206 in curing/processing, 135 in peeling, 6,157 are labourers, 145 in subsidiary works and 948 in other than fishing works respectively. Out of 5,511 persons enrolled into cooperative Societies, 3,699 are the members of Fisheries Cooperatives and 1,812 are members of other Cooperatives. Around 1,050 Trawlers, 72 Purseseiners, 1,194 mechanised, 1,962 motorized and 57 Non Motorised boats are operating in the District [8]. In Karnataka, Mangalore and Malpe fisheries harbours comprise $53 \%$ of the total marine fish landing and $43 \%$ of trawl fisheries in the State. Since 1959, the trawl fishery in the coast was gradual but over the years, fleet size of trawlers and trawling operation took qualitative and quantitative changes [9].

(d) Fisheries Resources: In 1956, Karnataka emerged to be a Maritime State and in 1957, it established Department of Fisheries. The State 4. ANALYSIS AND DISCUSSION :

Table 1: Socio Demographic Status

\begin{tabular}{|l|l|l|}
\hline Sl. No & Variable & Response \\
\hline
\end{tabular}

comprises $300 \mathrm{~km}$ long coast line stretching from Majali (Karwar) in the north to Ullal (Mangalore) in the south with three coastal districts via Uttar Kannada (160kms), Udupi (98kms) and Dakshina Kannada (Mangalore Taluk 42Kms) surrounded by the Western Ghats in east and Arabian Sea in the west. Traditionally, Karnataka Coast is known as "Mackerel Coast" covering 27000sq km of Continental Shelf and $87000 \mathrm{sq} \mathrm{km}$ of Exclusive Economic Zone rich with Pelagic Fishes like sardines, mackerels etc.

\section{CONTRIBUTION TO INDIAN ECONOMY :}

In Karnataka, the fish Production estimated around 2.0 lakh tonnes during the eighties was reached over 3.0 lakh tonnes by the mid nineties. During 2012-13, out of total fish production, 68 $\%$ share is contributed from marine fishing and rest $32 \%$ from the inland fisheries. Karnataka contributes $5.8 \%$ of India's fish production with 5.55 lakh tonnes during 2013-14. The current per capita fish availability in the state is estimated to be $6.8 \mathrm{~kg}$. The marine fish production quantity growth rate reached $4 \%$ during 2001-03 and $3 \%$ during 2003-04 respectively. The minimum value growth of $3 \%$ was noticed during 2003-04 and maximum growth of $76 \%$ during 2010-11. During 201213 was 0.96 lakh metric tonnes worth Rs. 854 crore was exported from Karnataka. The marine fish growth in quantity between 2000-01 to 2013-14 shows a positive growth except during 2001-02, 2004-05 and 2006-07 respectively. The growth of value of marine fish was positive from 2000-2013 except 2001-02 and 2007-08 with negative growth of $-20 \%$ and $-6.03 \%$ respectively. The minimum growth rate of $5 \%$ was recorded during 200-2001 and maximum growth rate of $69 \%$ in 2002-03 showing greater contribution of marine fishery in the total output of fish in the State. Dakshina Kannada district during 2011-12 and 2012-13 produced $39.57 \%$ and $38.66 \%$ of the total marine fish production of Karnataka. 
International Journal of Management, Technology, and Social

\begin{tabular}{|c|l|c|}
\hline 02 & Married & 77.40 \\
\hline 03 & Having 04 Dependents & 30.20 \\
\hline 04 & $\begin{array}{l}\text { Living in Nuclear } \\
\text { Family }\end{array}$ & 79.20 \\
\hline 05 & $\begin{array}{l}\text { With More than 16 } \\
\text { Years of Work } \\
\text { Experience }\end{array}$ & 83.00 \\
\hline 06 & $\begin{array}{l}\text { Having Primary \& High } \\
\text { School education }\end{array}$ & 32.10 \\
\hline 07 & Skilled Labourers & 83.00 \\
\hline 08 & $\begin{array}{l}\text { Earning between Rs. } \\
\text { 6,095 to 10,157 }\end{array}$ & 35.80 \\
\hline 09 & Lives in the Tiled House & 56.60 \\
\hline 10 & $\begin{array}{l}\text { Membership with } \\
\text { Association }\end{array}$ & 50.90 \\
\hline 11 & Having Food Security & 67.90 \\
\hline
\end{tabular}

\begin{tabular}{|c|l|c|}
\hline 05 & $\begin{array}{l}\text { Going along with 30 } \\
\text { Members for fishing }\end{array}$ & 54.7 \\
\hline 06 & $\begin{array}{l}\text { Fishing is Hereditary } \\
\text { Occupation }\end{array}$ & 83.0 \\
\hline 07 & $\begin{array}{l}\text { Contractor is the } \\
\text { Middlemen }\end{array}$ & 45.3 \\
\hline 08 & $\begin{array}{l}\text { Bank is the Source for } \\
\text { Loan }\end{array}$ & 32.1 \\
\hline 09 & $\begin{array}{l}\text { Middlemen derive } \\
\text { more Profit }\end{array}$ & 77.4 \\
\hline 10 & $\begin{array}{l}\text { Price is determined by } \\
\text { Auction }\end{array}$ \\
\hline 11 & $\begin{array}{l}\text { TV/FM/Newspaper } \\
\text { reading is the free } \\
\text { time Activity }\end{array}$ & 58.5 \\
\hline 12 & Working as Labourers & 77.4 \\
\hline
\end{tabular}

The general picture about socio demographic status of the respondents is presented in Table 1. Out of total 53 respondents, Majority 26 (49.1 $\%)$ respondents are above the age of 46 years, 41 (77.4 \%) are married, 16 (30.2 \%) with 04 dependents, 42 (79.2 \%) living in nuclear family, 44 (83.0 \%) with more than 16 years of work experience, 17 (32.1 \%) with Primary \& High school education, 44 (83.0 \%) are skilled workers, 19 (35.8 \%) earn between Rs. 6,095 to 10,157, $56.6 \%$ lives in the Tiled House, 27 (50.9 \%) participate in associations and 36 (67.9 $\%)$ having food security. It is inferred from the analysis that majority respondents are above 46 years of age, married, having 4 dependents, living in nuclear family, having more than 16 years of work experience with primary \& high school education working as skilled workers earning below Rs. 10,157 lives in the tiled house having membership with associations and food security.

Table 2: Occupational Profile

\begin{tabular}{|c|l|c|}
\hline $\begin{array}{c}\text { Sl. } \\
\text { No }\end{array}$ & Work Components & Percentage \\
\hline 01 & $\begin{array}{l}\text { Entry into Profession } \\
\text { between 14-18 Years } \\
\text { of age }\end{array}$ & 69.8 \\
\hline 02 & $\begin{array}{l}\text { 201-250 days of work } \\
\text { per Year }\end{array}$ & 60.4 \\
\hline 03 & $\begin{array}{l}12-14 \text { Hours work per } \\
\text { day }\end{array}$ & 39.6 \\
\hline 04 & Work in Day Shift & 52.8 \\
\hline
\end{tabular}

The occupational profile of the Respondents is represented in table 2. Out of total 53 respondents, Majority, 37 (69.8 \%) entered the fishing profession between their 14-18 years of age, 32 (60.4 \%) work between 201-250 days in a year, 21 (39.6 \%) work 12-14 hours per day, 28 (52.8 \%) works in the day shift, 29 (54.7 \%) are going with more than 30 members in a fishing trip, $44(83.0 \%)$ undertake fishing as hereditary occupation, 24 (45.3\%) contractor works as middlemen, 17 (32.1\%) bank is the source for any loan, 41 (77.4\%) middlemen derives more profit in fishing, 36 (67.9\%) price in fishing is determined by auction, 31 (58.5 \%) watch TV, listen to Fm and Read News Paper during free time, 41 (77.4 \%) works as labourers. It is inferred that majority respondents entered this occupation in very early ages, working around 250 days in a year with 12-14 hours of work per day working as labourers in the perseseiner boats as a hereditary occupation where price is determined by auction and the contractor acting as middlemen derives more profit. 
International Journal of Management, Technology, and Social

\begin{tabular}{|c|l|c|}
\hline $\begin{array}{r}\text { Sl. } \\
\text { No }\end{array}$ & \multicolumn{1}{|c|}{ Problem } & Percentage \\
\hline 01 & Cannot have food in Time & 64.2 \\
\hline 02 & Suffer from Economic Trouble & 64.2 \\
\hline 03 & Indebted & 60.4 \\
\hline 04 & No Protection for Old Age & 75.5 \\
\hline 05 & Fear of Accident & 49.1 \\
\hline 06 & Fear of Unemployment & 49.1 \\
\hline 07 & No fair Price & 60.4 \\
\hline 08 & Heavy Physical Labour & 83.0 \\
\hline 09 & $\begin{array}{l}\text { Inability to Pay for Health } \\
\text { Care }\end{array}$ & 69.8 \\
\hline 10 & Lengthy Working Hours & 71.7 \\
\hline
\end{tabular}

Table 4: Common Problems

\begin{tabular}{|l|l|l|}
\hline Sl. No & Problem & Percentage \\
\hline 01 & $\begin{array}{l}\text { Cannot have food in } \\
\text { Time }\end{array}$ & 64.2 \\
\hline 02 & $\begin{array}{l}\text { Suffer from } \\
\text { Economic Trouble }\end{array}$ & 64.2 \\
\hline 03 & Indebted & 60.4 \\
\hline 04 & $\begin{array}{l}\text { No Protection for } \\
\text { Old Age }\end{array}$ & 75.5 \\
\hline 05 & Fear of Accident & 49.1 \\
\hline 06 & $\begin{array}{l}\text { Fear of } \\
\text { Unemployment }\end{array}$ & 49.1 \\
\hline 07 & $\begin{array}{l}\text { No fair Price } \\
\text { Leavy Physical } \\
\text { Labour }\end{array}$ & 60.4 \\
\hline 08 & $\begin{array}{l}\text { Inability to Pay for } \\
\text { Health Care }\end{array}$ & 69.8 \\
\hline 09 & $\begin{array}{l}\text { Lengthy Working } \\
\text { Hours }\end{array}$ & 71.7 \\
\hline 10
\end{tabular}

Table 3: Occupational Hazards

\begin{tabular}{|c|l|c|}
\hline Sl. No & \multicolumn{1}{|c|}{ Hazard } & Percentage \\
\hline 01 & $\begin{array}{l}\text { Habituated to Tobacco } \\
\text { Consumption }\end{array}$ & 28.3 \\
\hline 02 & $\begin{array}{l}\text { Prone to Cyclone, Rain } \\
\text { \& Hot weather }\end{array}$ & 75.5 \\
\hline 03 & Suffer from Fever & 69.8 \\
\hline 04 & Suffer from Acidity & 39.6 \\
\hline 05 & $\begin{array}{l}\text { Suffer from Abdomen } \\
\text { Pain }\end{array}$ & 54.7 \\
\hline 06 & Suffer from Skin Disease & 39.6 \\
\hline 07 & $\begin{array}{l}\text { Suffer from Eye Problem } \\
08\end{array}$ & $\begin{array}{l}\text { Suffer from Hearing } \\
\text { Problem }\end{array}$ \\
\hline 09 & Suffer from Body Ache & 41.5 \\
\hline
\end{tabular}

The description about occupational hazards faced in fishing is represented in Table 3. Out of Total 53 respondents, Majority 15 (28.3\%) habituated in tobacco consumption, 40 (75.5\%) prone to natural risks like Cyclone, Rain \& Hot weather, 37 (69.8 \%) suffer from fever, 21 (39.6 $\%)$ suffer from acidity, 29 (54.7\%) suffer from abdomen pain, 21 (39.6 \%) suffer from skin and eye problems, 22 (41.5\%) suffer hearing problem and 28 (52.8\%) suffer body ache due to fishing activity respectively. The study revealed that, majority respondents are exposed to bad habits and natural hazards and suffering from health problems like fever, acidity, abdomen pain, skin diseases, eye sight problem, hearing difficulties and body ache due to uncontrollable elements in the occupation making the profession to be hazardous in nature. 
respondents are suffering with many problems including no intake of food in time, economic troubles, unfair price, heavy physical labour, inability to pay for health care, lengthy working hours and unsecure for the old age and uncertainty about accident and unemployment brings moral pressure on them.

Table 5: Non beneficiaries Profile

\begin{tabular}{|c|l|c|c|}
\hline $\begin{array}{c}\text { Sl. } \\
\text { No }\end{array}$ & Schemes & Frequency & Percentage \\
\hline 01 & $\begin{array}{l}\text { Credit } \\
\text { Schemes }\end{array}$ & 38 & 71.7 \\
\hline 02 & Training & 45 & 84.9 \\
\hline 03 & $\begin{array}{l}\text { Savings } \\
\text { Schemes }\end{array}$ & 36 & 67.9 \\
\hline 04 & $\begin{array}{l}\text { Legal } \\
\text { Awareness }\end{array}$ & 34 & 64.2 \\
\hline 05 & $\begin{array}{l}\text { Subsidy on } \\
\text { Equipments }\end{array}$ & 41 & 77.4 \\
\hline 06 & $\begin{array}{l}\text { Insurance } \\
\text { Schemes }\end{array}$ & 33 & 62.3 \\
\hline 07 & $\begin{array}{l}\text { Mutual } \\
\text { Guarantee } \\
\text { Schemes }\end{array}$ & 42 & 79.2 \\
\hline 08 & $\begin{array}{l}\text { Educational } \\
\text { Programmes }\end{array}$ & 34 & 64.2 \\
\hline 09 & $\begin{array}{l}\text { Medical } \\
\text { Services }\end{array}$ & 29 & 54.7 \\
\hline
\end{tabular}

\begin{tabular}{|c|l|c|c|}
\hline 10 & $\begin{array}{l}\text { Recreational } \\
\text { Facility }\end{array}$ & 34 & 64.2 \\
\hline 11 & Price Control & 46 & 86.8 \\
\hline 12 & $\begin{array}{l}\text { Housing } \\
\text { Schemes }\end{array}$ & 48 & 90.6 \\
\hline
\end{tabular}

The description about the non beneficiaries of various benefit schemes is represented in the Table 5. Out of total 53 respondents, Majority respondents are non beneficiaries of various schemes like $38(71.7 \%)$ credit schemes, 45 (84.9 \%) Training, 36 (67.9) Savings schemes, 34 (64.2 \%) Legal awareness Programmes, 41 (77.4 \%) Subsidy on equipments, 33 (62.3\%) Insurance Schemes, 42 (79.2 \%) Mutual Guarantee Schemes, 34 (64.2 \%) Educational Programmes, 29 (54.7 \%) Medical services, 29 (54.7 \%) Recreational facility, 46 (86.8 \%) Price control, 48 (90.6 \%) Housing schemes. The study revealed that, majority respondents are non beneficiaries of credit schemes, training programmes, savings schemes, legal awareness, subsidy on equipments, insurance schemes, mutual guarantee schemes, educational programmes, medical services, recreational facility, price control and housing schemes.

Table 6: Class, Health Hazards \& Social Security Status

\begin{tabular}{|c|c|c|c|}
\hline \multicolumn{4}{|c|}{ Socio-economic Class } \\
\hline Sl. No & Particulars & Frequency & Percentage \\
\hline \multirow[t]{3}{*}{01} & Lower Middle Class & 14 & 26.40 \\
\hline & Upper Lower Class & 39 & 73.60 \\
\hline & Total & 53 & 100.00 \\
\hline \multicolumn{4}{|c|}{ Occupational Health Hazards } \\
\hline \multirow[t]{4}{*}{02} & Healthy & 04 & 07.50 \\
\hline & Average Health & 35 & 66.00 \\
\hline & Risky & 14 & 26.40 \\
\hline & Total & 53 & 100.00 \\
\hline \multicolumn{4}{|c|}{ Social Security Measures } \\
\hline \multirow[t]{3}{*}{03} & Not Effective & 44 & 83.00 \\
\hline & Effective & 09 & 17.00 \\
\hline & Total & 53 & 100.00 \\
\hline
\end{tabular}




\section{HYPOTHESES TESTING :}

\section{$\mathrm{H}_{1}$ : There is a significant association between Socio-economic Class and Occupational Health Hazards}

Table 7: Socio-economic Class \& Occupational Health Hazards

\begin{tabular}{|l|c|c|c|c|}
\hline \multirow{2}{*}{ Socio-economic Class } & \multicolumn{4}{|c|}{ Occupational Health Hazards } \\
\cline { 2 - 5 } & Healthy & $\begin{array}{c}\text { Average } \\
\text { Health }\end{array}$ & Risky & Total \\
\hline Lower Middle Class & 03 & 07 & 04 & $\mathbf{1 4}$ \\
\hline Upper Lower Class & 01 & 28 & 10 & $\mathbf{3 9}$ \\
\hline Lower Class & 00 & 00 & 00 & $\mathbf{0 0}$ \\
\hline \multicolumn{1}{|c|}{ Total } & $\mathbf{0 4}$ & $\mathbf{3 5}$ & $\mathbf{1 4}$ & $\mathbf{5 3}$ \\
\hline
\end{tabular}

\section{Pearson Chi Square Value is $\mathbf{5 . 6 3 2}$}

The relationship between Socio-economic class and Occupational Health Hazards is represented in the Table 7. At 02 degrees of freedom at 0.05 significance level, calculated Chi Square value is 5.632 and Table Value is 5.991. As the Calculated Value is less than the Table Value, the hypothesis is "Accepted". The analysis

$\mathrm{H}_{2}$ : There is a significant association between Work Experience and Occupational Health Hazards Table 8: Work Experience \& Occupational Health Hazards

\begin{tabular}{|l|c|c|c|c|}
\hline \multirow{2}{*}{ Work Experience } & \multicolumn{4}{|c|}{ Occupational Health Hazards } \\
\cline { 2 - 5 } & Healthy & $\begin{array}{c}\text { Average } \\
\text { Health }\end{array}$ & Risky & Total \\
\hline Less than 5 Years & 00 & 01 & 00 & $\mathbf{0 1}$ \\
\hline 6-10 Years & 01 & 02 & 00 & $\mathbf{0 3}$ \\
\hline 11-15 Years & 01 & 04 & 00 & $\mathbf{0 5}$ \\
\hline More than 16 Years & 02 & 28 & 14 & $\mathbf{4 4}$ \\
\hline \multicolumn{1}{|c|}{ Total } & $\mathbf{0 4}$ & $\mathbf{3 5}$ & $\mathbf{1 4}$ & $\mathbf{5 3}$ \\
\hline
\end{tabular}

\section{Pearson Chi Square Value is 7.496}

The relationship between work experience and occupational Health Hazards is represented in the table 8. At 06 degrees of freedom at 0.05 significance level, calculated Chi Square value is 7.496 and Table Value is 12.592. As the Calculated Value is less than the Table Value,

$\mathrm{H}_{3}$ : There is a significant association between Work Experience \& Social Security Measures

Table 9: Work Experience \& Social Security Measures

\begin{tabular}{|c|c|c|c|}
\hline \multirow{2}{*}{ Work Experience } & \multicolumn{3}{|c|}{ Social Security Measures } \\
\cline { 2 - 4 } & Not Effective & Effective & Total \\
\hline Less than 5 Years & 00 & 01 & $\mathbf{0 1}$ \\
\hline 6-10 Years & 01 & 02 & $\mathbf{0 3}$ \\
\hline 11-15 Years & 05 & 00 & $\mathbf{0 5}$ \\
\hline More than 16 Years & 38 & 06 & $\mathbf{4 4}$ \\
\hline Total & $\mathbf{4 4}$ & $\mathbf{0 9}$ & $\mathbf{5 3}$ \\
\hline
\end{tabular}

Pearson Chi Square Value is $\mathbf{1 1 . 5 1 4}$ the hypothesis is “Accepted". The analysis reveals that out of 53 respondents, majority 44 respondents with more than 16 years of work experience have Average Health showing significant relationship between Work experience and Occupational Health Hazards. 
The relationship between Work Experience and Social Security Measures is represented in the table 9. At 03 degrees of freedom at 0.05 significance level, calculated Chi Square value is 11.514 and Table Value is 7.815. As the Calculated Value is more than the Table Value, the hypothesis is "Rejected". The analysis reveals that out of 53 respondents, majority 44 respondents with more than 16 years of work experience reported that social security measures are not effective showing there is no significant relationship between Work experience and Social Security Measures.

\section{OUTCOME OF THE STUDY :}

There is ample scope to increase the income of fisheries Co-operative Societies thereby improve the income of fisher folk by providing infrastructural support to adopt improved fishing and fish culture practices on scientific basis. The social, economic and political status of the fisher folk can be improved through education of the fisherfolks [10]. In the developing countries, small scale fishermen are living below the subsistence level or within the lowest socioeconomic groups facing absolute or relative poverty, in spite of remarkable development in fisheries and economic growth of the country. Many have not adopted the advanced fishing technology, no large scale employment, capital market distortions and limited mobility of the small scale fishermen. There is a need to analyse the available policies to improve their socioeconomic conditions to maximize their contribution to economic, cultural and social development [11]. The geographical positioning systems installed in the Trawlers and off shore operations focusing the market demands lead to increase juvenile exploitation. There is a need to make policies which could be implemented as a fisheries guidelines for the trawl fisheries to avoid juvenile catches [12]. Reduced catches even with more efforts and unequal distribution of output value among the traditional fishermen have forced them to adopt more active fishing gear to compete with trawlers and purseseiners as a course of their effort to cope with advancement in the profession. It is inevitable for the fishermen to motorize their crafts to sustain in the competition, which force them to be indebted to the middlemen and merchants thereby loose control over the sale of their catch. It is important that, the stack holders in order to manage the fisheries resources, should work on the rights, demands, education and training of the poor fishermen in partnership with public institutions [13]. The ideal fisheries management policy should choose inputs to create impact on employment to boost the economic condition of that locality [14].

\section{CONCLUSION :}

Sustainable growth through economic empowerment is possible by identifying job opportunities, reducing power politics at workplace, granting decision making, leadership and career enrichment [15]. Since fisheries involve an inherent interplay between humans and the natural world, as both an economic 'industry' and a socio cultural foundation for people and communities, it is necessary to maintain a healthy resource base fundamental to fisheries as to other renewable resource systems over the millennia. State of Karnataka, inspite of having the largest water spread area, contributes 8 per cent of the Indian fish Production. There exists many technical and socio economic hurdles to increase the fish production. Several fishing organizations, cooperatives are trying to culminate socio, economic and cultural difficulties in this regard [16]. It is found that, the economic development of fishery is reducing in the south west coast of India due to intensifying regional dependence on external capital, economic impoverishment, pollution of coastal waters, marine resource depletion due to over exploitative fishing [17]. The steps shall be introduced with regarding to compensation system against the losses, capital inputs, profit sharing, labour intensive employments, open access to resources to protect fishing communities from exploitations. The Fishing villages shall be provided with clean drinking water, housing, health services, infrastructural support, roads, public transport, credit facilities and other support services for storage, processing and marketing activities [18]. The marine fisheries has emerged as the important 
sector in the last five decades by increasing its yield both quantitatively and qualitatively shifting itself from the traditional subsistence supplementary activity to commercial activity of coastal population [19]. Socio-economic development of the fishermen community is possible by adopting improved fishing and fish farming methods along with proper training in this regard [20]. Social Security Schemes are the Social Protection meet the local needs with resources committed to safeguard the interest of the excluded majority [21]. The labourers working in the Unorganised sectors is miserable. Creating awareness about health, family life, nutrition, child care, rights and civil responsibilities among the rural people shall be performed in a consistent pattern. [22]

\section{REFERENCES :}

[1] Pradeep M. D., Ravindra \& Ramjani Sab T. (2017) A Study on the Prospects and Problems of Unorganised Labours in India, International Journal of Applied and Advanced Scientific Research, 2 (1), 94100.

[2] My Gov India. (2017). Fortnightly Newsletter, 2 (11), $27^{\text {th }}$ November, 12.

[3] Dakshina Kannada District- Human Development Index.(2014). 161-163.

[4] Sujatha H.R \& Mahesh V Mudhol (2006). Electronic Information Resources on Fisheries: A Study, Annuals of Library \& Information Studies, 53, June, 96-102.

[5] Mulla A.M. \& Shiralashetti A.S. (2015). An overview of Marine Fisheries of India and Coastal Karnataka:Its Present Status', Abhinav International Monthly Refereed Journal of Research in Management \& Technology, 4 (11), November, 30-42.

[6] Sen Amartya (1984). Resources, Values and Development; Harvard University Press, U.S.A. 13.

[7] Younis, A.S \& Donaldson, G. (1982). Fishery Sector Policy, The World Bank, Washington, 5-6.

[8] Marine Fisheries Census, Karnataka (2010),
Central Marine Fisheries Research Institute Kochi \& Indian Council of Agricultural Research, New Delhi, 1-135.

[9] Mohamed K.S., Muthiah C, Zacharia P.U, Sukumaran K.K, Rohit P. \& Krishnakumar P.K. (1998). Marine Fisheries of Karnataka State, India. NAGA 21(2), 10-15.

[10] Basavakumar K. V., Devendrappa S \& Srenivas S. T. (2011). A study on profile of fishing community of a village in Karnataka, Karnataka Journal of Agricultural Science, 24 (5), 684-687.

[11] Smith, I.R. (1979) A Rresearch Framework for Traditional Fisheries'. ICLARM Stud. Rev (2), 40 p.

[12] Dinesh Babu \& Radhakrishnan E.V. (2009). Trawl Fishery of Juvenile Fishes along Mangalore-Malpe Coast of Karnataka and its Impact on Fish Stock, Asian Fisheries Science22, 491-500.

[13] Kurian, John (1994). Socioeconomic Issues in Coastal Fisheries Management, Proceedings of the IPFC Symposium Held in Conjunction with the Twenty-fourth Session of IPFC Bangkok, Thailand, 23-25 November, 1993.

[14] Heady, C. (2000). Natural resource Sustainability and Poverty reduction, Environmental Development Economics, 5(3), 241-258.

[15] Sonia Delrose Noronha, Aithal P.S. \& Pradeep M.D.(2017). Study on the Policy Framework towards work life balance in India, International Journal of Multidisciplinary Research \& Modern Education, 3(2), 11-16.

[16] Rahim, K.M.B. and Padhy, M. (1994). Scope and Constraints of Inland Pisciculture in West Bengal: A Case Study of Birbhum District, Giriyappa S (Ed), Daya Publishing House, New Delhi, 141158.

[17] Angle, P.S. (1983). Goa: an Economic Review, Bombay, Goa Hindu Association Kala Vibhag, Panaji, Goa, 36. 
[18] Tietze U, Groenewold G, and Marcoux A (2000). Demographic Change in Coastal Fishing Communities and its implications for the Coastal Environment, FAO Fisheries Technical Paper 403, Rome.

[19] Mulla A. M \& Shiralashetti A.S. (2015). An Overview of Marine Fisheries of India and Coastal Karnataka: Its Present Status, Abhinav, International Monthly Refereed Journal of Research in Management \& Technology, 4 (11), November, 30-42.

[20] Basavakumar K. V., Devendrappa S \& Srenivas S. T. (2011). A Study on Profile of Fishing Community of a Village in Karnataka, Karnataka Journal of Agricultural Sciences, 24 (5), 684-687.
[21] Pradeep M.D. \& M. L. Kalicharan, (2016). Social Security Measures for Indian Workforce - A Legal Intervention, International Journal of Computational Research and Development, 1 (1), 47-57.

[22] Pradeep M.D. \& Deeksha (2016). MultiDimensional approach for empowermentEffective strategies to face problems and challenges of women in India, International Journal of Scientific Research \& Modern Education (IJSRME), I ( I), 744-755. 